\title{
Religious Nationalism as Solution in the Chaotic Social, Economics and the Business Reality
}

Yogi Simhanath

Peneleh Research Institute Nepal and Gorakhnath Cult Nepal

karnabahadurthapa@yahoo.com

ARTICLE INFO

Article history

Received 28 October 2019

Revised 20 February 2020

Accepted 30 April 2020

Keywords

Religious natiionalism

National interest

globalization

\section{ABSTRACT}

The purpose of this article is to highlight the importance of religious nationalism to protect vital national interests, maintain stability and preservation of core values. The expression of the constitution of Indonesia is a guarantor in integrating the people from all groups and strata of Indonesian society. It ensures a favorable internal and external condition. Religious nationalism is super glue that bonds the people, religions and the nation as a single entity. This is still utmost relevant in the pandemic.

This is an open access article under the CC-BY-SA license

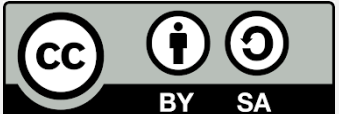

\section{Introduction}

Indonesia, a house of two hundreds and seventy million people has a deeper bond in sharing language, culture, heritage, religion which is a very powerful centripetal force that supports the idea of Indonesian nation and identity. The religion combined with nation constitutes a singular entity as "religious nationalism".

In addition, the expression of the Constitution of Indonesia ensures the inclusion of people fro all classes and strata of Indonesian society. It ensures a favorable internal and external condition to protect vital national interests, maintain stability and preservation of core values. The history of Indonesia with its continuity and changes is a tutor for all times to come. In this sense, religious nationalism is a super-glue that connects people, religions and the country as a single entity. This has been placed in the writing of Indonesian symbol of Garuda (Java Eagle) which reads "Bhinneka Tunggal Ika" - unity in diversity [1].

The end of Cold-War after forty-five years, a new force emerged as globalization which has been found borderless and stateless [2]. There is no conceptual clarity whether it is a state centric, region centric or a global centric force. The question remains unanswered. It is not an interdependent force to ally to protect the nation and not an incarnation to worship. It has just filled the air.

University faculties, available literatures and behavior of states on religious nationalism are primarily divided into two key areas. The scriptures of religion is divided as the Eastern and the Western wisdom. Nationalism is divided as the first world and the third world. This is a clear division contributing as the primary sources of paradox. The discussion here on religion on the Eastern wisdom, Swami Vivekananda's [3] philosophy and message on the universal religion has been consulted as main source. Likewise, 
Samuel P. Huntington's "The Clash of Civilizations and the Remaking of World Order" [4] has been chosen the view from the west. Tony Nader's comprehensive work on "Human Physiology: Expression of Veda and the Vedic Literature" is a fusion of science and Veda. This is completely different from the religion and the nation.

Swami Vivekananda's speech was delivered on the 11th of September 1983 (some 126 years ago) in the "World Parliament of Religions" to discover from competent men what light religion has to throw on the great problems of the present age, which continued for 17 days [5]. The important questions were connected with Temperance, Labor, Education, Wealth and Poverty." Swami Vivekananda emphasized that Vedanta has discovered the common ground among all religions.

Samuel P. Huntington's much appreciated book "The Clash of Civilizations and the Remaking of World Order" attempts to capture realistic thoughts on contemporary issues. It is no doubt that this is an unparalleled intellectual contribution in capturing the issues in world affairs. This is not a point of disagreement on such a wonderful work. The epistemological observation on cultures, weapon proliferation, democracy, Human Rights, economics, demography, Islam and so on is comprehensively addressed. However, it does not refer philosophical foundations and religious dimension which occupies almost one half of the statecraft.

Finally, the roles and responsibilities of Indonesian youth on religious nationalism have been presented. The younger generation has a noble task to bridge between the grandparents and grand children and conveying predecessor's message to the younger.

Besides external dynamics of threats on nationalism, there are equally or perhaps more pressing internal issues dogging the states. State planners, especially in developing nations, are prone to focus primarily on internal issues. Small, weak and developing nations have little to influence at the global level. Multiple lapses and geopolitical situation have all along posed growing number of challenges confronting nationalism. Many challenges including ethnic subversion, internal insurgency, demographic movement and unresolved issues collectively form internal crises on nationalism.

National character is the only software of the mind applicable to protect the core values of religious nationalism. There are three key mantras of national character which are: 1) responsibility in shoulder 2) honesty in the heart and 3. understanding in the head. This can effectively serve on the Save Our Soul (SOS) call of the nation; youth are put into the front burner with the religious and emotional charge as the nation first philosophy.

The roots of religious nationalism are very deep. There are many unresolved thorny problems between the neighbors set by the colonial masters. Even today resources remain as curse to many countries. Asymmetric agreements have been signed for the better Physical quality of life of the other. With these aforementioned practices in global order it is really hard to come into a consensus to foresee, what next?. One must be optimistic against all adversaries. The cosmic powers and five elements (sky, air, water, fire and ether) are present in a natural and cosmic order friendly to us. Today, we are facing an unprecedented crisis of our time. The world has become borderless by questioning "who is who" and where is the boundary between the "the first World and the Third World". In spite of the rigorous efforts of the scientists, medical innovations and discoveries proved non-existent for dead. A hypothesis could be drawn here that, is corona virus 2020 is a battle between men and cosmic sensor of mother earth? Or we invested more than required 
on defense and security sectors at the cost of human value. The scientists from various faculties will attempt to seek the answer in future.

\section{Result and Discussion: Religious Nationalism as a Defense amidst Corona Virus-2019 Pandemic}

Attempt has been made to discuss defense related five dimensions to justify the topic. A high fever is believed an automatic activation of defense mechanism within a human body. Similarly, intrusion of outsiders into the internal autonomous functioning of a state is a threat to it. Defense system has to be understood in two aspects. The first is the compliance towards regional and global standards for a win-win situation and the second is the unique standard of individual countries with homegrown standards of their own. Objectively speaking, defense is a self help phenomenon. A traumatic situation within a country begins to countdown hours, minutes and seconds. One needs to have its own survival strategy by strengthening the "first responder's capacity". That is a real defense.

\subsection{Spiritual Dimension}

Five key elements of our existence in universe; sky, air, water, fire and ether are our sources of survival including all creatures of earth. The expression of nature has not been properly decoded by modern human. We did not pay attention to our indigenous people, animals and birds symbolism, intergeneration acceptance of culture who were fairly capable and benevolent to us to translate the expression of nature and continuity of our values. For example even a shaman can tell us many hidden truths. Our own people started leveling it as superstition.

Moreover, Astrological predictions from eastern knowledge has been ignored by modern education system. This is the eye of Veda [6]. The metaphysical dimensions of modern science always asked to produce physical evidences. Astro scientists started forecasting ferocious attributes of Saturn (satunus) for the year 2020. This year Saturn, a planet known for justice and unbiased nature has come back to its own house Capricorn (Capricornus) after 30 years. This combination has buttressed Saturn to be very very powerful. The brutality of this planet since the end of 2019, has advanced to punish for the accumulated sin over the last 30 years throughout the world.

\subsection{Political Dimension}

In the continuity and changes in the history of our nations, the Corona Virus-2020 will be recorded and remembered for its brutality. The brutality is not just only about the devastating effect of the virus itself, but also political effect it brings, such as the case in the US [7]. The post corona virus period demands a lesson learned model for future political decisions. All the dimensions of statecraft operate under the political road map. The leaders will be in a new situation for a rational choice from the lessons of history and opening a window for new opportunities. It will be largely determined by the participatory approach to reinvent for a homegrown national strategy. The "we" concept such as Bhinneka Tunggal Ika mentioned earlier, and inner strength of our society are crucial components for our existence as a nation. Religious nationalism, such as being expressed in Indonesian constitution will help to bring unity during the pandemic. 


\subsection{Economic Dimension}

Comparing the expenditures between defense and basic human needs of the people, London based publication of the International Institute for Strategic Studies (IISS), a Britain based think tank study explicitly states how much a nation allocates for defense. In addition, some countries spend resource allocated for other purpose are spent in defense.

\subsection{Environmental Dimension}

Environment is an emerging issue for coexistence between human and nature. How much we can extract from the nature that is unlimited. Similarly, the killing of animals, birds, fish and other creatures are available for food consumption. Human never conceives they were born as mammals. Eating other creatures is not their need but a choice of test.

Destructions of jungles, air pollution are justifies through periodic conferences and summits. The countries and rulers are undermining the environmental lifeline as their own blank cheque. The tragic part of the pollution and degradation is one is consuming the resources at the cost of the other. Religious nationalism will act upon injustice to environment since it is an obligation to take care of nature as taught in religions.

\subsection{Military Dimension}

The following points will be discussed under military dimension:

1. Proportion and Justification of expendures

2. Modernization requirements of armed forces

3. History

4. Ratio between citizen and soldiers

5. Alliances and pacts

6. The global and regional trend

7. SWOT analysis

\subsection{Need for Re-conceptualizing the World Order}

This is a very complicated issue to reconceptualize existing policies and procedu res. There is no readymade answer for it. How one involves its own key stakeholders. The preconditions required for states to ensure their vital national interest and take a course of breakthrough needs a skill and courage. Occasionally, the loyalty of our own stakeholders is a problem faced by the states. The rational choice for states must be determined. This is a model of national stakeholders to incorporate input into the policy in a given time, situation, resources, priority, stability and cause of concern to enhance national power. Religious nationalism must be taken into account in re-conceptualizing the word order, so that the world will not fall back into its lust-materialistic state as it is now.

\section{Conclusion}

What next? What strategies post-corona virus-2019 will the states formulate will be premature to speculate. Finding a nature friendly and citizen centered concept could be a healthy conclusion but the choice will not be so easy. How much the political leaders will stipulate the fact that every citizen is an integral component of national defence and 
security to cope with manmade and natural calamities of any kind. Our citizens are the first responder.

However, if Religious Nationalism is embraced which emphasizes obedience to the Divine as well the unity and social justice for the people, then any chaos will be surpassed. We hope to see a better civilization in the future as long we can learn from the divine teaching and the divine reflection on the universe.

\section{References}

[1] Farisi MI. Bhinneka Tunggal Ika [unity in diversity]: From dynastic policy to classroom practice. J Soc Sci Educ 2014. doi:10.2390/jsse-v14-i1-1261.

[2] Diener AC, Hagen J. Theorizing Borders in a 'Borderless World': Globalization, Territory and Identity. Geogr Compass 2009;3:1196-216. doi:10.1111/j.17498198.2009.00230.x.

[3] Melloni J. Swami Vivekananda. Voces la mística II, Herder; 2012, p. 113-5. doi:10.2307/j.ctvt7x7p4.29.

[4] Evans P, Huntington SP. The Clash of Civilizations and the Remaking of the World Order. Contemp Sociol 1997. doi:10.2307/2654621.

[5] Mulder JM, Seager RH. The World's Parliament of Religions: The East/West Encounter, Chicago, 1893. J Am Hist 1995;82:1244. doi:10.2307/2945213.

[6] Narayanaswamy V. Origin and development of ayurveda: (a brief history). Anc Sci Life 1981.

[7] Jean T. Black Lives Matter: Police Brutality in the Era of COVID-19. N C Med J 2020. 